\title{
ACCOUNTING, ANALYSIS AND AUDITING
}

\author{
БУХГАЛТЕРСЬКИЙ ОБЛІК, \\ АНАЛІЗ ТА АУДИТ
}

УДК 657.633.5

\section{ВНУТРІШНІЙ КОНТРОЛЬ ДОГОВІРНИХ ОПЕРАЦІЙ ЛІСОГОСПОДАРСЬКИХ ПІДПРИЕМСТВ}

\author{
Наталія Голячук; Сергій Голячук
}

\author{
Луцький національний технічний університет, Луиьк, Украйна
}

\begin{abstract}
Резюме. Діяльність підприємства не може бути ефективною за відсутності належного контролю за ї̈ виконанням. Об'єктами внутрішньогосподарського контролю договірного процеесу є господарські відносини підприємства, щзо перевіряються на предмет відповідності чинному законодавству, відповідності діяльності підприємства та умовам договору. Роль облікових прачівників в управлінні договірним прочесом є визначальною, щзо зумовлено необхідністю облікової інформації на кожній зі стадій договірного процесу. Узв'язку з тим, щзо договір є правовою основою здійснення обміну, обов'язковою є участь юриста або юридичного відділу, щзо забезпечує правильність оформлення договору з юридичної точки зору. Для ефективного управління договірним прочесом на підприємстві внутрішній контроль дочільно проводити за етапами: попередній, поточний і підсумковий. Для лісогосподарських підприємств розроблена модель внутрішнього контролю договірних відносин, складовими якої є: об'єкти контролю, джерела інформаиї, методичні прийоми контролю, узагальнення результатів $i$ контроль за реалізацією прийнятих рішень. Для покращення внутрішнього контролю запропоновано створити на підприємстві окрему групу внутрішнього контролю за виконанням договірних операцій. До складу групи дочільно ввести двох спеціалістів; ревізор - інженер лісового господарства та ревізор бухгалтер - економіст. Метою роботи групи внутрішнього контролю за виконанням договорів $є$ пошук иляхів підвищення результативності реалізації договірного процесу. Для кожного учасника групи внутрішнього контролю за виконанням договірних операцій розроблено програму контролю, яка дозволить проводити якіснышу перевірку виконання договорів, надавати керівництву інформацію про відхилення від порядку виконання робіт, термінів їх виконання для прийняття вчасних управлінських рімень.
\end{abstract}

Ключові слова: внутрішній контроль, договір, договірні операчіï, лісогосподарське підприємство.

https://doi.org/10.33108/galicianvisnyk_tntu2020.01.152

Отримано 03.02.2020

\section{UDC 657.633.5}

\section{INTERNAL CONTROL OF AGREEMENT OPERATIONS OF FORESTRY ENTERPRISES}

\author{
Nataliia Holiachuk; Serhii Holiachuk \\ Lutsk National Technical University, Lutsk, Ukraine
}

\begin{abstract}
Summary. The enterprise activity cannot be effective if there is no proper control over its performance. The objects of internal economic control of the agreemant process are the enterprise economic relations, which
\end{abstract}


are tested for conformance with the current legislation, accordance with the enterprise activity and the agreement terms. The role of accounting staff in managing the agreement process is defining one caused by the need for accounting information at each stage of the agreement process. Due to the fact that the agreement is the legal basis for the exchange, the engagement of the lawyer or legal department ensuring the proper agreement drafting from the legal viewpoint is required. In order to manage effectively the agreement process at the enterprise, it is reasonable to carry out the internal control according to the following stages: preliminary, current and final. For forestry enterprises, the model of internal control of agreement relations consisting of: control objects, information sources, methodical methods of control, generalization of results and control of the adopted decision implementations is developed. In order to improve internal control, it is proposed to set up a separate group of internal control over the performance of agreement operations at the enterprise. It is advisable to include two specialists in the group; auditor-forestry engineer and auditor-accountant-economist. The objective of the group work of internal control of the agreement implementation is to find ways to improve the agreement process effectiveness. For each group member of internal control of agreement operations execution, the control program is developed. This program makes it possible to carry out more effective control of the agreement execution, to provide managers with information concerning deviations from the procedural arrangement, terms of their execution for timely management decisions making.

Key words: internal control, agreement, agreement operations, forestry enterprise.

Постановка проблеми. Контроль як одна 3 функцій управління сприяє розробленню якісних управлінських рішень та їх виконанню, тобто досягненню короткотермінових і довготермінових цілей підприємства. Діяльність підприємства не може бути ефективною за відсутності належного контролю за іiі виконанням. Об'єктами внутрішньогосподарського контролю договірного процесу є господарські відносини підприємства, що перевіряються на предмет відповідності чинному законодавству, відповідності діяльності підприємства та умовам договору [1].

Аналіз останніх досліджень і публікацій. Організаційні й методичні питання бухгалтерського обліку та внутрішнього контролю виконання договірних зобов'язань розглядали такі вчені: Городиський М. П., Затока Т. В., Кирик Т. В., Кобецька Н. Р., Кузьмін Дн. Л., Орлов І. В., Романчук К. В., Стрибко Т. І., Шкабрій Н. О. та інші.

Романчук К. В. у дослідженнях довела, що для забезпечення створення системи внутрішньогосподарського контролю договірного процесу найдоцільнішим для великих підприємств є створення окремого структурного підрозділу або введення до штату окремого працівника, за яким у посадовій інструкції необхідно закріпити відповідні функціональні обов'язки з контролю за реалізацією договірного процесу. На середніх і малих підприємствах здійснення контрольних функцій доцільно передбачати в посадових інструкціях за працівниками, функції яких пов'язані з участю в договірному процесі [2].

Результати дослідження Шкабрій Н. О. надали змогу запропонувати удосконалення організаційних засад аудиту з придбання запасів за договорами купівліпродажу, а саме, обгрунтувати склад суб'єктів внутрішнього і зовнішнього аудиту, їх організаційно-правовий статус [3].

Для дослідження специфіки внутрішнього контролю способів забезпечення виконання договірних зобов'язань, Затокою Т. В. визначено основні завдання внутрішнього контролю забезпечення виконання договірних зобов'язань на стадіях договірного процесу в розрізі попереднього, поточного та наступного контролю, виділено об'єкти та суб'єкти внутрішнього контролю, розкрито порядок його організації [4]. 
Метою дослідження $є$ дослідження стану внутрішнього контролю договірних операцій на лісогосподарських підприємствах та розроблення пропозицій щодо його удосконалення.

Постановка завдання. Для досягнення поставленої мети необхідно виконати такі завдання: розглянути етапи внутрішнього контролю, побудувати модель внутрішнього контролю договірних відносин, запропонувати програму контролю за виконанням договорів.

Виклад основного матеріалу. Для забезпечення системи внутрішньогосподарського контролю договірного процесу найдоцільнішим для лісогосподарських підприємств є створення окремого структурного підрозділу або введення до штату окремого працівника, за яким у посадовій інструкції необхідно закріпити відповідні функціональні обов’язки з контролю за реалізацією договірного процесу.

Роль облікових працівників в управлінні договірним процесом є визначальною, що зумовлено необхідністю облікової інформації на кожній зі стадій договірного процесу. У зв'язку з тим, що договір $є$ правовою основою здійснення обміну, обов'язковою є участь юриста або юридичного відділу, що забезпечує правильність оформлення договору 3 юридичної точки зору. Працівники юридичного відділу та бухгалтерської служби тісно співпрацюють, оскільки найменша зміна умов договору 3 точки зору господарського та цивільного законодавства призведе до зміни економічних та податкових наслідків виконання конкретного договору [2].

Для ефективного управління договірним процесом на підприємстві внутрішній контроль доцільно проводити за етапами, а саме: попередній, поточний і підсумковий.

На попередньому етапі підписання договорів необхідно перевірити у потенційних виконавців наявність усіх ліцензій та дозволів на виконання лісогосподарських робіт. А потенційних покупців доцільно перевірити на платоспроможність для виявлення ризиків щодо непогашення боргових зобов'язань.

Поточний внутрішній контроль договірних операцій головним бухгалтером безпосередньо пов'язаний із перевіркою фінансових документів, який грунтується на виконанні платіжної дисципліни по підписаних договорах надання послуг з лісівництва, договорах купівлі-продажу, договорах підряду на виконання лісогосподарських робіт тощо.

Прийняття рішення на підсумковому етапі $\epsilon$ комплексним процесом. Керівник підприємства повинен володіти детальними результатами попереднього і поточного контролю. При цьому важливим моментом є виконання прийнятих рішень i аналіз їх наслідків для лісогосподарського підприємства.

Модель внутрішнього контролю договірних відносин наведено на рисунку 1.

Складовими запропонованої моделі є: об’єкти контролю, джерела інформації, методичні прийоми контролю, узагальнення результатів і контроль за реалізацією прийнятих рішень. Якісне управління договірними відносинами дасть можливість вчасно виконувати взяті зобов'язання та оплачувати роботи, виконані замовниками за договорами. 


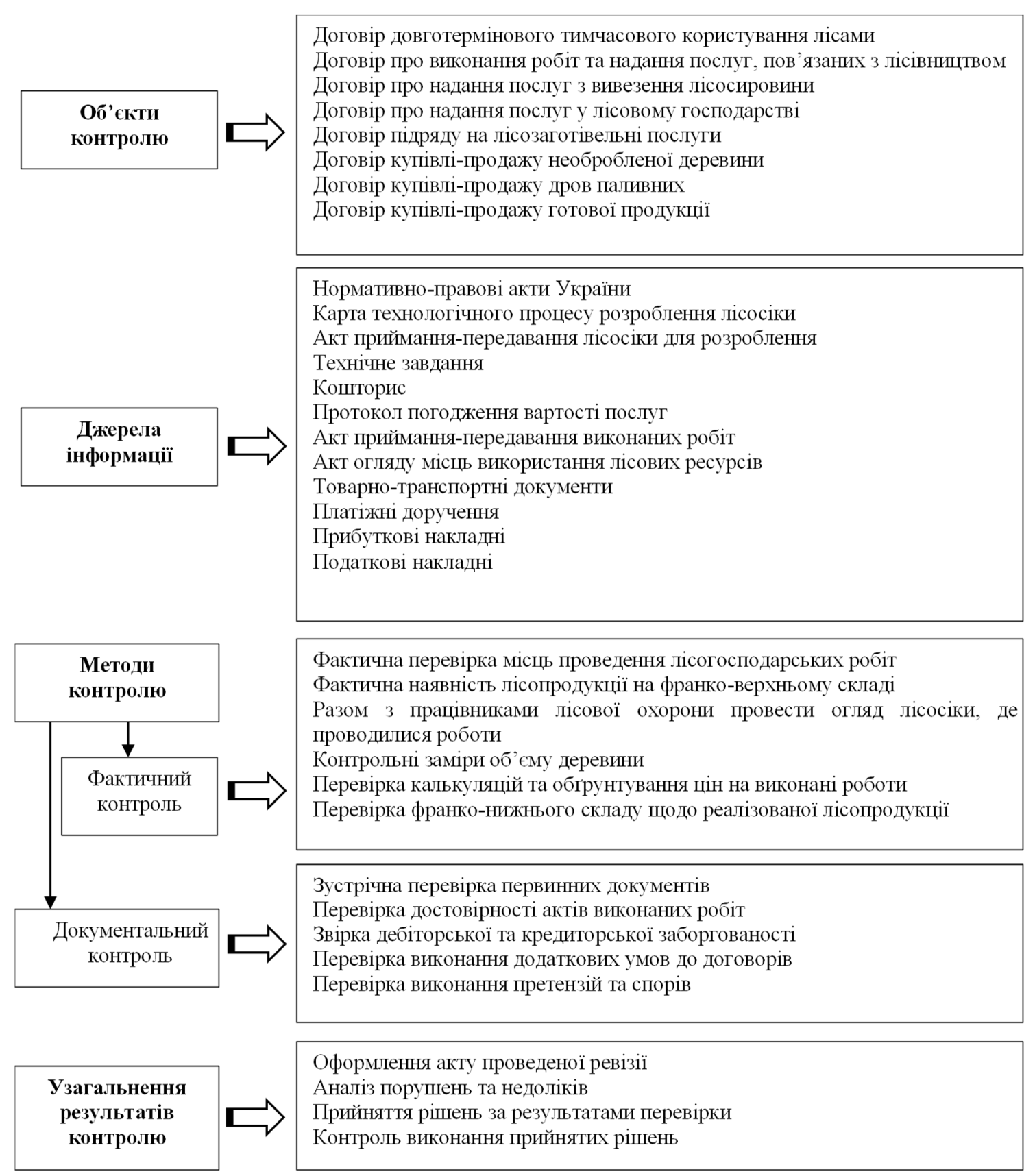

Рисунок 1. Модель внутрішнього контролю договірних відносин

Figure 1. Model of internal control of agreement relations

Розроблено автором.

На лісогосподарських підприємствах процесом контролю за виконанням договірних відносин займаються головний бухгалтер та головний лісничий. Для покращення внутрішнього контролю пропонуємо створити на підприємстві окрему групу внутрішнього контролю за виконанням договірних операцій. До складу групи доцільно ввести двох спеціалістів:

1 - ревізор - інженер лісового господарства (має вищу освіту та кваліфікацію інженер лісового господарства; розуміє та чітко розбирається в усіх господарських процесах, пов’язаних $з$ лісом); 
2 - ревізор - бухгалтер - економіст (має вищу освіту в галузі економіки лісового господарства, чітко розуміє порядок та особливості складання договорів, відображення виконаних робіт, наданих послуг, реалізованої продукції в системі рахунків бухгалтерського обліку; порядок складання первинних, зведених документів та формування звітності; має навики аналітичної роботи: аналіз, опрацювання великих масивів інформації, економіко-математичний аналіз).

Метою роботи групи внутрішнього контролю за виконанням договорів $є$ пошук шляхів підвищення результативності реалізації договірного процесу.

Завдання групи внутрішнього контролю за виконанням договірних операцій:

1) забезпечення керівництва лісогосподарського підприємства достовірною інформацією про кількість та якість підписаних договорів, надійність партнерів, виконавців та покупців;

2) перевірка відповідності здійснюваних операцій вимогам законодавства;

3) аналіз правильності та своєчасності реєстрації операцій, що здійснюються у процесі виконання договорів;

4) встановлення достовірності й точності відображення даних за такими операціями у фінансовій звітності;

5) сприяння вдосконаленню систем обліку та контролю, які діють на підприємстві, та підвищенню ефективності їх функціонування.

Кожен учасник групи внутрішнього контролю за виконанням договірних операцій складає для себе програму контролю, приклад якої наведено в таблицях 1 та 2.

Таблиця 1. Програма контролю договірних операцій

Виконавець: ревізор - інженер лісового господарства

Table 1. The agreement operations control program

Contractor: auditor - forestry Engineer

\begin{tabular}{|c|c|c|c|}
\hline Назва робіт & 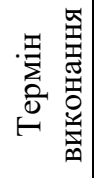 & $\begin{array}{c}\text { Особи, які можуть } \\
\text { бути задіяні в процесі } \\
\text { перевірки }\end{array}$ & : \\
\hline 1 & 2 & 3 & 4 \\
\hline $\begin{array}{l}\text { Перевірка наявності ліцензії на проведення робіт, пов'язаних з } \\
\text { лісовим господарством }\end{array}$ & & $\begin{array}{l}\text { Інженер з охорони } \\
\text { праці }\end{array}$ & \\
\hline $\begin{array}{l}\text { Перевірка наявності дозволів Держгірпромнагляду на виконання } \\
\text { робіт підвищеної небезпеки, на експлуатацію машин, } \\
\text { механізмів, устаткування підвищеної небезпеки }\end{array}$ & & $\begin{array}{l}\text { Інженер з охорони } \\
\text { праці }\end{array}$ & \\
\hline $\begin{array}{l}\text { Перевірка виконавця робіт на дотримання положень чинного } \\
\text { законодавства з охорони праці, пожежної безпеки, охорони } \\
\text { природи на лісосіці, що розробляється }\end{array}$ & & $\begin{array}{l}\text { Інженер з охорони } \\
\text { праці }\end{array}$ & \\
\hline $\begin{array}{l}\text { Перевірка правильності складання карти технологічного } \\
\text { процесу розроблення лісосіки }\end{array}$ & & $\begin{array}{l}\text { Інженер лісового } \\
\text { господарства }\end{array}$ & \\
\hline $\begin{array}{l}\text { Перевірка достовірності даних, відображених в акті приймання- } \\
\text { передачі лісосіки для розроблення }\end{array}$ & & Лісничий & \\
\hline Перевірка очищення лісосіки від порубувальних решток & & Лісничий & \\
\hline $\begin{array}{l}\text { Перевірка наявності лісопродукції на франко-верхньому складі } 3 \\
\text { вибірковою перевіркою запасу вирубаної деревини }\end{array}$ & & $\begin{array}{l}\text { Лісничий, інженер } \\
\text { лісового господарства }\end{array}$ & \\
\hline Перевірка наявності пнів на місцях вирубки & & Лісничий & \\
\hline $\begin{array}{l}\text { Перевірка наявності лісорубних квитків та відповідність даних у } \\
\text { них даним лісосіки }\end{array}$ & & $\begin{array}{l}\text { Бухгалтерія, відділ } \\
\text { лісового господарства }\end{array}$ & \\
\hline $\begin{array}{l}\text { Перевірка послідовності та черговості виконання робіт, } \\
\text { зазначених у акті приймання-передачі лісосіки для розробки }\end{array}$ & & $\begin{array}{l}\text { Інженер лісового } \\
\text { господарства }\end{array}$ & \\
\hline
\end{tabular}


Закінчення таблиці 1

\begin{tabular}{|l|l|l|c|}
\hline \multicolumn{1}{|c|}{1} & 2 & \multicolumn{1}{|c|}{3} & 4 \\
\hline Перевірка акту готовності лісосіки до розроблення & & $\begin{array}{l}\text { Лісничий, інженер } \\
\text { лісового господарства }\end{array}$ & $\begin{array}{l}\text { Лісничий, інженер } \\
\text { лісового господарства }\end{array}$ \\
\hline $\begin{array}{l}\text { Перевірка переліку послуг, пов’язаних з лісівництвом, } \\
\text { зазначених у технічному завданні }\end{array}$ & \\
\hline
\end{tabular}

Розроблено автором.

Таблиця 2. Програма контролю договірних операцій Виконавець: ревізор - бухгалтер - економіст

Table 2. The agreement operations control program Contractor: auditor - accountant - economist

\begin{tabular}{|c|c|c|c|}
\hline Назва робіт & 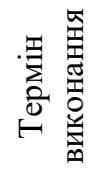 & $\begin{array}{l}\text { Особи, які можуть } \\
\text { бути задіяні в } \\
\text { процесі перевірки }\end{array}$ & 窇 \\
\hline Перевірка кошторису на послуги, які надаються за договором & & Головний економіст & \\
\hline $\begin{array}{l}\text { Перевірка протоколу погодження вартості послуг, які надаються } \\
\text { за договором }\end{array}$ & & Головний економіст & \\
\hline Перевірка калькуляцій на послуги, пов’язані з лісівництвом & & $\begin{array}{l}\text { Головний економіст, } \\
\text { бухгалтер }\end{array}$ & \\
\hline Перевірка акту приймання-передачі виконаних робіт & & Бухгалтер лісництва & \\
\hline Перевірка наявності документів за договором & & Юрист, бухгалтер & \\
\hline $\begin{array}{l}\text { Перевірка наявності платіжних доручень на оплату та виписок } \\
\text { банку на проведення платежів }\end{array}$ & & $\begin{array}{l}\text { Бухгалтер по } \\
\text { розрахунках }\end{array}$ & \\
\hline $\begin{array}{l}\text { Перевірка правильності відображення господарських операцій } \\
\text { за рахунком } 63 \text { «Розрахунки } 3 \text { постачальниками та підрядниками» }\end{array}$ & & $\begin{array}{l}\text { Бухгалтер по } \\
\text { розрахунках }\end{array}$ & \\
\hline $\begin{array}{l}\text { Перевірка правильності відображення господарських операцій } \\
\text { за рахунком } 36 \text { «Розрахунки з покупцями та замовниками» }\end{array}$ & & $\begin{array}{l}\text { Бухгалтер по } \\
\text { розрахунках }\end{array}$ & \\
\hline Перевірка сплати податків за договорами & & $\begin{array}{l}\text { Бухгалтер по } \\
\text { розрахунках }\end{array}$ & \\
\hline Перевірка графіка виконання договорів & & Юрист & \\
\hline
\end{tabular}

Розроблено автором.

Найважливішим етапом контролю $є$ інвентаризація. В ході інвентаризації перевіряється наявність усіх документів, якими підтверджуються виконання договорів. Не менш важливим $є$ застосування ревізором прийомів документальної перевірки. За допомогою формальної, арифметичної, логічної, нормативно-правової, зустрічної та взаємної перевірки здійснюється контроль відповідних первинних документів, облікових реєстрів та фінансової звітності підприємства у частині відображення заборгованості покупців, замовників, виконавців, постачальників, а також фактів надходження грошових коштів на рахунок підприємства.

На етапі перевірки ревізори можуть виявити:

- відсутність або неправильне оформлення договорів;

- договори наявні, але не зареєстровані в журналі реєстрації договорів;

- заниження запасу заготовленої деревини;

- кількість пеньків не відповідає кількості спиляних дерев;

- після закінчення робіт не прибрана територія, не вивезені рештки;

- наявність фіктивних продажів, коли продукція відображена як реалізована, але реально не передана дебітору;

- невідповідність сум у первинних документах;

- виправлення сум у виписках банку тощо. 
Висновки. Наявність групи внутрішнього контролю за виконанням договірних операцій дозволить вчасно виявляти та усувати порушення при виконанні договірних зобов'язань, контролювати оплату й надходження коштів на рахунок підприємства. Розроблена програма контролю договірних операцій дозволить проводити якіснішу перевірку виконання договорів, надавати керівництву інформацію про відхилення від порядку виконання робіт, термінів їх виконання для прийняття вчасних управлінських рішень.

Conclusions. The availability of the group of internal control of agreement operations execution makes it possible to determine in time and to eliminate the violations in the agreement obligations execution, to control payment and receipt of funds at the enterprise expense. The developed agreement operations control program enables to carry out more effective control of agreement execution, to provide managers with information concerning deviations from the procedural arrangement, terms of their execution for timely management decisions making.

\section{Список використаної літератури}

1. Романчук К. В. Контроль укладання та виконання господарських договорів. Вісник ЖДТУ. 2005. № 3 (33). С. 197-204.

2. Романчук К. В. Організація та методика бухгалтерського обліку договірного процесу (на прикладі діяльності промислових підприємств України): автореф. дис... канд. екон. наук: 08.06.04. Київ, 2005. $21 \mathrm{c}$.

3. Шкабрій Н. О. Аудит операцій з придбання запасів за договором купівліпродажу: автореф. дис. ... канд. екон. наук: 08.00.09. Житомир, 2016. 23 с.

4. Затока Т. В. Бухгалтерський облік забезпечення виконання договірних зобов'язань: теорія $\mathrm{i}$ методика: автореф. дис. ... канд. екон. наук: 08.00.09. Житомир, 2012. 19 с.

\section{References}

1. Romanchuk K. V. Kontrol' ukladannia ta vykorystannia hospodarskyh. Control of conclusion and execution of economic contracts. Visnyk ZhDTU. 2005. No. 3 (33). P. 197-204.

2. Romanchuk K. V. Orhanizatsiia ta metodyka bukhhalterskoho obliku dohovirnoho protsesu (na prykladi diialnosti promyslovykh pidpryiemstv Ukrainy). Organization and method of accounting of contractual process (on the example of activity of industrial enterprises of Ukraine). Phd Thesis. Kyiv, 2005. P. 21.

3. Shkrabii N. O. Audyt operatsii z prydbannia zapasiv za dohovorom kupivliprodazhu. Audit of operations on purchase of stocks under the contract of sale. Phd Thesis. Zhytomyr, 2016. P. 23.

4. Zatoka T. V. Bukhhalterskyi oblik zabezpechennia vykonannia dohovirnykh zoboviazan: teoriia $\mathrm{i}$ metodyka. Accounting for the performance of contractual obligations: theory and methodology. Phd Thesis. Zhytomyr, 2012. P. 19. 